\title{
Foliar Phosphorus and Zinc Application Improve Growth and Productivity of Maize (Zea mays L.) Under Moisture Stress conditions in Semi-Arid
}

\section{Climates}

\author{
Amanullah $^{1 *}$, Amir Saleem ${ }^{1}$, Asif Iqbal' ${ }^{1}$ and Shah Fahad ${ }^{2}$
}

${ }^{1}$ Department of Agronomy, Faculty of Crop Production Sciences, The University of Agriculture, Peshawar, Pakistan

${ }^{2}$ Crop Physiology and Production Center (CPPC), College of Plant Science and Technology Huazhong Agricultural University, Wuhan, Hubei, PR China

\begin{abstract}
Foliar fertilizers application is beneficial for improving growth, yield and yield components of field crops under moisture stress condition in semiarid climates. Field experiment was conducted to study the response of dryland maize (Zea mays L., cv. Azam) to foliar phosphorus (1, 2 and $3 \% \mathrm{P}$ ) and zinc levels $(0.1,0.2$, and $0.3 \% \mathrm{Zn}$ ) and their application time $\left(T_{1}=a t\right.$ boot stage and $T_{2}=$ at silking stage) at the Agronomy Research Farm of The University of Agriculture Peshawar during summer 2014. The experiment was conducted under moisture stress condition (with three irrigations only: $1^{\text {st }}$ at emergence, $2^{\text {nd }}$ at knee height and third at seed development stage). The results revealed that foliar treated plots (rest) had significantly $(P<0.05)$ better growth, higher yield components and grain yield than control (no foliar spray). Plots applied with $3 \%$ foliar $\mathrm{P}$ had improved growth and resulted in significantly $(P<0.05)$ higher yield and yield components. Yield and yield components of maize increased significantly $(P<0.05)$ with $0.3 \%$ foliar $\mathrm{Zn}$ application. Maize growth, yield and yield components also increased significantly $(P<0.05)$ when foliar nutrients were applied at early stage (booting) than late (silking) application. It was concluded from this study that application of $3 \%$ foliar $\mathrm{P}+0.3 \%$ foliar $\mathrm{Zn}$ at boot stage improve growth and increase maize productivity and profitability under moisture stress condition in semiarid climates.
\end{abstract}

Keywords: Maize; Growth; Yield; Foliar; Phosphorus; Zinc; Phosphorus $\times$ zinc; Limited irrigation

\section{Introduction}

Maize (Zea mays L.) is the $3^{\text {rd }}$ highest yielding cereal crop in the world after wheat and rice. In Pakistan 64\% maize is grown in irrigated and $36 \%$ in rainfed areas. In northwest Pakistan (Khyber Pakhtunkhwa) having semiarid climate maize yield is very low1868 kg ha-1 [1]. Improper water and nutrients management are the two main factors that adversely affect the growth and crop productivity under moisture stress (drought) condition in the Khyber Pakhtunkhwa (province of Pakistan [2]. Balance fertilization is essential for improving crop growth [3], increasing yield and harvest index [4], grain quality [5,6], fertilizer use efficiency [7] and profitability [8-11].

The diffusion coefficient of soil applied phosphorus $(\mathrm{P})$ is very low and plants cannot get $\mathrm{P}$ when needed [12] particularly in the calcareous soils under semiarid condition [4]. Therefore, foliar P application is very important under semiarid climate. The mechanistic processes by which foliar applied nutrients are taken up are through leaf stomata [13] and hydrophilic pores within the leaf cuticle [14]. Foliar applications of $\mathrm{KH}_{2} \mathrm{PO}_{4}$ is reported to delay leaf senescence and increase winter wheat grain yields during hot and dry summers $[15,16]$. Increased yields in barley were obtained using dilute solutions of foliar $P$ [17]. Foliar fertilization with nitrogen, phosphorus, and potassium (N-P-K) can be supplemented with soil applied fertilizers but cannot replace soil fertilization in the case of maize $[18,19]$ reported that when initial $\mathrm{P}$ deficiency symptoms appeared 25 days after sowing in wheat, higher doses of ammonium phosphate as a foliar spray gave the greatest reduction in $\mathrm{P}$ deficiency and highest yields. Foliar $\mathrm{P}$ can increases fertilizer use efficiency [20].

Zinc $(\mathrm{Zn})$ is very important for various physiological functions in plants [21-24]. Zinc deficiency not only reduces the crop production but also cause $\mathrm{Zn}$ deficiency in our diet [25]. Application of $\mathrm{Zn}$ to zinc deficient soils increased maize grain yield as well as the $\mathrm{Zn}$ and $\mathrm{N}$ concentrations in maize grains. Application of $\mathrm{Zn}$ increases dry matter by increasing leaf chlorophyll contents [26] and increase in $\mathrm{N}$ and $\mathrm{P}$ efficiencies [27]. In soils the $\mathrm{P}$ interferes $\mathrm{Zn}$ uptake by the plants $[2,28]$. About the interaction of zinc and phosphorus numerous studies have been done and all confirms this point that zinc and phosphorus imbalance in the plant, as a result excessive accumulation of phosphorus, causing zinc imposed deficiency [29]. Therefore, foliar $\mathrm{Zn}$ application is a simple way for making quick correction of plant nutritional status in wheat [30] and maize [31]. Foliar application of $\mathrm{Zn}$ enhances the uptake and accumulation of nitrogen and finally increased the maize grain. Foliar application of $\mathrm{Zn}$ significantly improved starch contents of forage maize [32]. In case of greater bioavailability of the grain zinc derived from foliar applications than from soil, agronomic bio-fortification would be a very attractive and useful strategy in solving zinc deficiencyrelated health problems globally and effectively $[24,33,34]$.Therefore, foliar application of nutrients to crop plants is very effective for improving crop growth and yield [35]. However, there is lack of research on crops response to combined use of foliar P and $\mathrm{Zn}$. The present study was therefore designed to investigate impact of various foliar P (1, 2 and 3\%) and foliar Zn levels (0.1, 0.2 and $0.3 \%)$ applied at different growth stages ( $\mathrm{T} 1=$ boot stage and $\mathrm{T} 2=$ silking stage) on the growth and yield of maize (Zea mays L., cv. Azam) under limited irrigation in semi-arid condition.

*Corresponding author: Amanullah, Department of Agronomy, Faculty of Crop Production Sciences, The University of Agriculture, Peshawar, Pakistan, Tel: +92 91 9221144; E-mail: amanullah@aup.edu.pk

Received July 01, 2016; Accepted September 30, 2016; Published October 07, 2016

Citation: Amanullah, Saleem A, Iqbal A, Fahad S (2016) Foliar Phosphorus and Zinc Application Improve Growth and Productivity of Maize (Zea mays L.) Under Moisture Stress conditions in Semi-Arid Climates. J Microb Biochem Technol 8 433-439. doi: 10.4172/1948-5948.1000321

Copyright: (c) 2016 Amanullah, et al. This is an open-access article distributed under the terms of the Creative Commons Attribution License, which permits unrestricted use, distribution, and reproduction in any medium, provided the original author and source are credited. 


\section{Materials and Methods}

To study the effect of foliar phosphorus $(\mathrm{P})$ and zinc $(\mathrm{Zn})$ levels on growth and yield of maize (Zea mays L., cv. Azam), field experiment was conducted at the Agronomy Research Farm of The University of Agriculture Peshawar, during summer, 2014. The experiment consisted of three foliar $\mathrm{P}$ levels $\left(\mathrm{P}_{1}=1, \mathrm{P}_{2}=2\right.$ and $\left.\mathrm{P}_{3}=3 \%\right)$, three foliar $\mathrm{Zn}$ levels $\left(\mathrm{Zn}_{1}=0.1, \mathrm{Zn}_{2}=0.2\right.$ and $\left.\mathrm{Zn}_{3}=0.3 \%\right)$, two application times $\left(\mathrm{T}_{1}=\right.$ boot stage and $\mathrm{T}_{2}=$ silking stage) and one control $\left(\mathrm{P}_{0} \mathrm{Zn}_{0}\right)$. The experiment was laid out in a randomized complete block design having three replications. Each replication consisted of 10 treatments per replication with a plot size of $3 \mathrm{~m} \times 3 \mathrm{~m}$ ( 4 rows, $3 \mathrm{~m}$ long and $70 \mathrm{~cm}$ apart) at the rate of 66, 000 plants ha ${ }^{-1}$. Local variety of maize "Azam" was used as test crop and sown on $29^{\text {th }}$ June, 2014. Data were recorded on plant height, leaf area index, number of grains ear-1 ${ }^{-1}$ thousand grains weight, biomass yield, grain yield and shelling percentage. Data on plant height $(\mathrm{cm})$ at physiological maturity was recorded with the help of meter rod by selecting five plants randomly from each plot and then average plant height was calculated. Leaf area index at silking was calculated as leaf area plant ${ }^{-1}$ (mean single leaf area $\mathrm{x}$ leaves plant $^{-1}$ ) divided by ground area per plant. Number of grains ear ${ }^{-1}$ was calculated on ten randomly selected ears from each plot and then averaged. Thousand grains weight were calculated by taking of randomly 1000 grains from seed lot of each plot and was weighted with the help of electronic balance. Data on biomass yield was recorded by harvesting the four central rows in each plot, the material was sun dried for several days and weighed, and then converted into biomass yield in $\mathrm{kg} \mathrm{ha}^{-1}$. For grain yield, the four central rows of each treatment harvested for biomass yield, the ears were separated, dried, threshed, grains were cleaned and weighed and then converted into grain yield $\left(\mathrm{kg} \mathrm{ha}^{-1}\right)$. Shelling percentage was calculated by using the formula [36,37]:

$$
\text { Shelling percentage }(\%)=\frac{\text { Grains weight of } 10 \text { ears } x 100}{\text { Total weight of } 10 \text { ears }}
$$

\section{Statistical Analysis}

The data were statistically analyzed according to Steel et al. [38] for randomized complete block design and means among different treatment were composed using least significant differences (LSD) test $(\mathrm{P} \leq 0.05)$. Brief ANOVA and level of significance is given in Table 1.

\section{Results}

\section{Growth}

Plant height $(\mathrm{cm})$ was significantly $(\mathrm{P}<0.05)$ affected by control vs. rest (average of all foliar $\mathrm{P}$ and $\mathrm{Zn}$ treated plots), application time (T), foliar $\mathrm{Zn}$, foliar $\mathrm{P}, \mathrm{Zn} \times \mathrm{P}$ and $\mathrm{T} \times \mathrm{P}$ (Table 1$)$. The rest had produced significantly taller plants $(187 \mathrm{~cm})$ over control $(180 \mathrm{~cm})$ (Table 2). Maize produced taller plants with early (boot stage) foliar application than late (silking stage) application. Among the foliar P levels, plant height was increased with $3 \% \mathrm{P}(189.2 \mathrm{~cm})$ and lower plant height $(184.3 \mathrm{~cm})$ was obtained with $1 \% \mathrm{P}$. Among the foliar $\mathrm{Zn}$ levels, the tallest plants were recorded with $0.3 \% \mathrm{Zn}(188.1 \mathrm{~cm})$ and minimum $(185 \mathrm{~cm})$ with $0.2 \%$ foliar $\mathrm{Zn}$. Interaction between $\mathrm{P} \times \mathrm{Zn}$ indicated that at lowest foliar P level ( $1 \% \mathrm{P})$; all the foliar $\mathrm{Zn}$ levels resulted in shorter plants (Figure 1). At the highest foliar P (3\%), application of $0.1 \%$ and $0.3 \%$ foliar $\mathrm{Zn}$ increased plant height over $0.2 \%$ foliar $\mathrm{Zn}$ (Figure 1). However, $0.2 \%$ foliar $\mathrm{Zn}$ increased plant height over $0.1 \%$ and 0.3 foliar $\mathrm{Zn}$ when applied in combination with $2 \% \mathrm{P}$ (Figure 1). Interaction between $\mathrm{P} \times \mathrm{T}$ indicated that the highest foliar $\mathrm{P}$ level (3\%) resulted in the tallest plant heights when applied at boot stage (Figure 2). Application of $2 \%$ foliar $P$ was better in terms of taller plants when

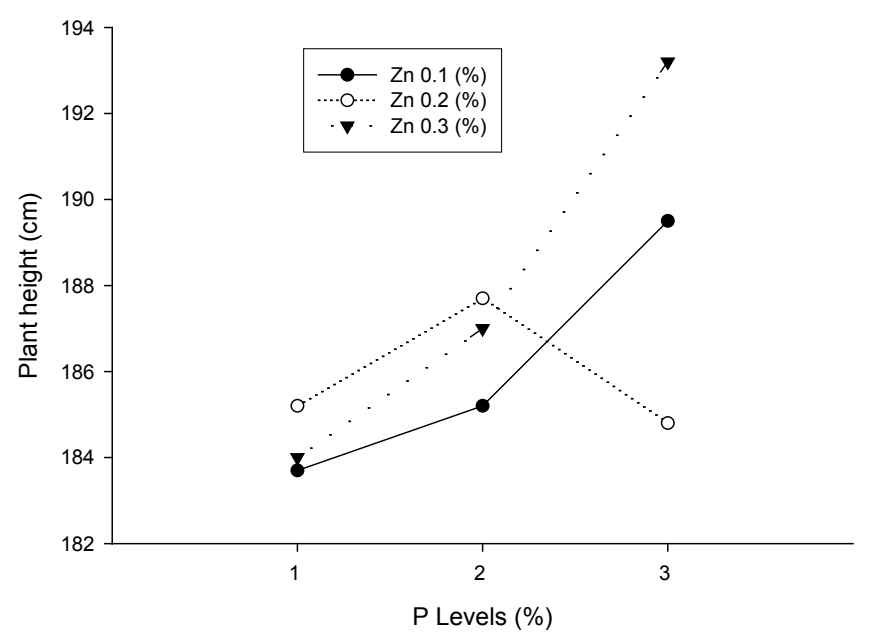

Figure 1: Interaction between foliar $P$ and foliar $\mathrm{Zn}(\mathrm{P} \times \mathrm{Zn})$ influence plant height $(\mathrm{cm})$ in maize (Zea mays).

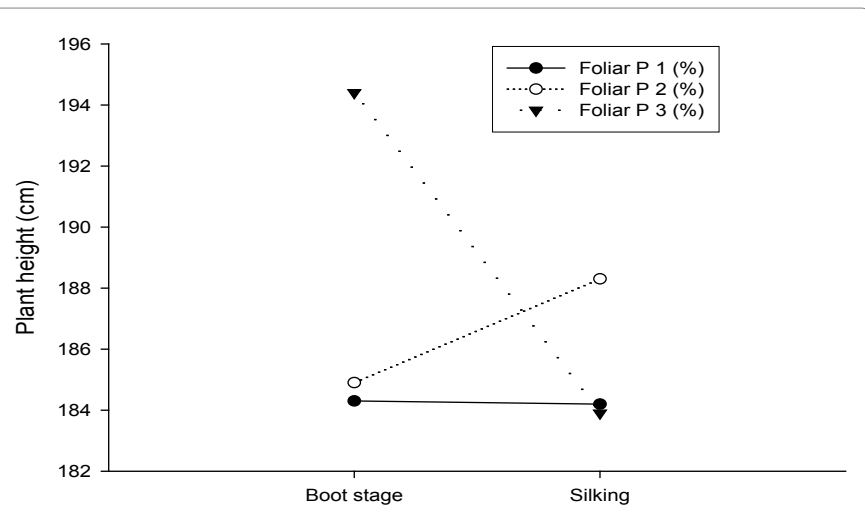

Figure 2: Interaction between foliar $P$ and application time $(P \times T)$ influence plant height $(\mathrm{cm})$ in maize (Zea mays).

applied at silking stage (Figure 2). However, no difference in plant heights was observed when $0.1 \%$ foliar $\mathrm{Zn}$ was applied either at booting or sulking (Figure 2).

Leaf area index (LAI) was significantly $(\mathrm{P}<0.05)$ affected by control vs. rest, foliar $\mathrm{P}$ and $\mathrm{Zn}$ levels (Table 1). The rest had produced significantly higher LAI over control (Table 2). Maximum LAI was obtained with $3 \%$ foliar P (2.7) and minimum (2.5) was obtained with $1 \%$ foliar P. Among the foliar Zn levels, maximum LAI was obtained with $0.3 \% \mathrm{Zn}$ (2.8) and lowest with $0.1 \%$ foliar $\mathrm{Zn}(2.5)$.

\section{Yield components}

Number of grains ear ${ }^{-1}$ was significantly $(\mathrm{P}<0.05)$ affected by control vs. rest, foliar $\mathrm{P}$ and $\mathrm{Zn}$ levels, and $\mathrm{P} \times \mathrm{Zn}$ interaction (Table 1). The rest had produced significantly more number of grains ear ${ }^{-1}$ (456) as compared to control (321) (Table 2). Among the foliar P levels, the highest number of grains ear ${ }^{-1}$ was obtained with $2 \% \mathrm{P}(478.5)$ and lower with $3 \% \mathrm{P}$ (429.6). Among the foliar $\mathrm{Zn}$ levels, maximum number of grains ear-1 were recorded with $0.2 \% \mathrm{Zn}$ (498.7) and lowest number of grains ear ${ }^{-1}$ were obtained with $0.3 \% \mathrm{Zn}$ (411.8). Interaction between $\mathrm{P} \times \mathrm{Zn}$ indicated that at lowest foliar P level (1\% P); application of $0.2 \%$ foliar $\mathrm{Zn}$ increased number of grains ear ${ }^{-1}$ than other $\mathrm{P}$ and $\mathrm{Zn}$ 


\begin{tabular}{|c|c|c|c|c|c|c|c|}
\hline Source of Variance & Plant height $(\mathrm{cm})$ & Leaf area index & Grains ear $^{-1}$ & 1000 grains eight $(g)$ & Biomass yield (kg ha-1) & Grain yield (kg ha-1) & Shelling (\%) \\
\hline Control vs. Rest & *** & *** & *** & $* * *$ & *** & *** & *** \\
\hline Application time (T) & * & * & * & * & *** & $* \star *$ & *** \\
\hline Zinc (Zn) & $* *$ & $\star * *$ & ** & * & $\star * *$ & $* * *$ & $* * *$ \\
\hline Phosphorus (P) & *** & *** & ** & * & * & *** & *** \\
\hline$P \times Z n$ & *** & ns & * & * & ns & ** & ns \\
\hline $\mathrm{Zn} \times \mathrm{T}$ & ns & ns & ns & ns & ** & $* * *$ & * \\
\hline$P \times T$ & *** & ns & ns & ns & ns & ns & ns \\
\hline$P \times Z n \times T$ & ns & ns & ns & ns & ns & ns & ns \\
\hline
\end{tabular}

${ }^{*},{ }^{* *},{ }^{* * *}$ indicates that data is significant at 5,1 and $0.1 \%$ level of probability, respectively. The word ns stand for the non-significant data at $5 \%$ level of probability

Table 1: Analysis of variance for plant height $(\mathrm{cm})$, leaf area index, number of grains ear ${ }^{-1}$, thousand grains weight, biomass yield $\left(\mathrm{kg} \mathrm{ha}^{-1}\right)$, grain yield $\left(\mathrm{kg} \mathrm{ha}^{-1}\right)$ and shelling percentage $(\%)$ of maize as affected by foliar phosphorus $(P)$ and zinc $(\mathrm{Zn})$ levels and their application time $(\mathrm{T})$.

\begin{tabular}{|c|c|c|c|c|c|c|c|}
\hline Treatments & $\begin{array}{l}\text { Plant height } \\
\text { (cm) }\end{array}$ & Leaf area index & $\begin{array}{c}\text { Number of Grains } \\
\text { ear }^{-1}\end{array}$ & $\begin{array}{c}\text { Thousand Grains } \\
\text { Weight (g) }\end{array}$ & $\begin{array}{l}\text { Biomass yield } \\
\left(\mathrm{kg} \mathrm{ha}^{-1}\right)\end{array}$ & $\begin{array}{c}\text { Grain yield } \\
\left(\mathrm{kg} \mathrm{ha}^{-1}\right)\end{array}$ & $\begin{array}{c}\text { Shelling } \\
\text { Percentage (\%) }\end{array}$ \\
\hline P 1\% & $184.3 \mathrm{c}$ & $2.5 \mathrm{c}$ & $460.5 b$ & $213.50 \mathrm{~b}$ & $9471 \mathrm{~b}$ & $3560 \mathrm{c}$ & $75.8 \mathrm{c}$ \\
\hline P $2 \%$ & $186.6 \mathrm{~b}$ & $2.6 \mathrm{~b}$ & $478.5 \mathrm{a}$ & $216.60 \mathrm{a}$ & $9544 a b$ & $3624 \mathrm{~b}$ & $77.1 \mathrm{~b}$ \\
\hline P 3\% & $189.2 \mathrm{a}$ & $2.7 \mathrm{a}$ & $429.6 \mathrm{c}$ & $205.50 \mathrm{c}$ & 9567 a & 3708 a & $78.2 \mathrm{a}$ \\
\hline SD & \pm 2.5 & \pm 0.1 & \pm 24.7 & \pm 5.7 & \pm 50.1 & \pm 74.2 & \pm 1.2 \\
\hline Zn $0.1 \%$ & $186.1 \mathrm{~b}$ & $2.5 b$ & $458.2 \mathrm{~b}$ & $206.90 \mathrm{~b}$ & $9321 \mathrm{c}$ & $3446 \mathrm{c}$ & $73.9 \mathrm{c}$ \\
\hline Zn $0.2 \%$ & $185.9 \mathrm{~b}$ & $2.5 \mathrm{~b}$ & 498.7 a & $217.70 \mathrm{a}$ & $9506 \mathrm{~b}$ & $3603 \mathrm{~b}$ & $76.4 \mathrm{~b}$ \\
\hline Zn $0.3 \%$ & $188.1 \mathrm{a}$ & $2.8 \mathrm{a}$ & $411.8 \mathrm{c}$ & $211.00 \mathrm{~b}$ & 9754 a & $3842 a$ & $80.8 \mathrm{a}$ \\
\hline SD & \pm 1.2 & \pm 0.2 & \pm 43.5 & \pm 5.5 & \pm 217.3 & \pm 199.4 & \pm 3.5 \\
\hline Boot stage & $187.9 \mathrm{a}$ & $2.7 \mathrm{a}$ & $441.7 b$ & $211.00 \mathrm{a}$ & 9779 a & 3698 a & $78.6 \mathrm{a}$ \\
\hline Silking stage & $185.5 b$ & $2.5 \mathrm{~b}$ & $470.7 \mathrm{a}$ & $212.70 \mathrm{a}$ & $9276 \mathrm{~b}$ & $3563 b$ & $75.5 b$ \\
\hline SD & \pm 1.7 & \pm 0.1 & \pm 20.5 & \pm 1.2 & \pm 355.7 & \pm 95.5 & \pm 2.2 \\
\hline Control plots & $180.0 \mathrm{~b}$ & $2.0 \mathrm{~b}$ & $321.2 b$ & $213.50 \mathrm{~b}$ & $8841 b$ & $3289 \mathrm{~b}$ & $72.0 \mathrm{~b}$ \\
\hline Treated plots & $187.0 \mathrm{a}$ & $3.0 \mathrm{a}$ & $456.4 \mathrm{a}$ & $216.60 \mathrm{a}$ & 9527 a & 3631 a & $77.0 \mathrm{a}$ \\
\hline SD & \pm 4.9 & \pm 0.7 & \pm 95.6 & \pm 2.2 & \pm 485.1 & \pm 241.8 & \pm 3.5 \\
\hline
\end{tabular}

Where SD stands for standard deviations

Means of the same category followed by different letters are significantly different from each other using LSD test $(P \leq 0.05)$

Table 2: Plant height $(\mathrm{cm})$, leaf area index, number of grains ear ${ }^{-1}$, thousand grains weight, biomass yield $\left(\mathrm{kg} \mathrm{ha}^{-1}\right)$, grain yield $\left(\mathrm{kg} \mathrm{ha}^{-1}\right)$ and shelling percentage $(\%)$ of maize as affected by foliar phosphorus $(P)$ and zinc $(Z n)$ levels and their application time $(T)$.

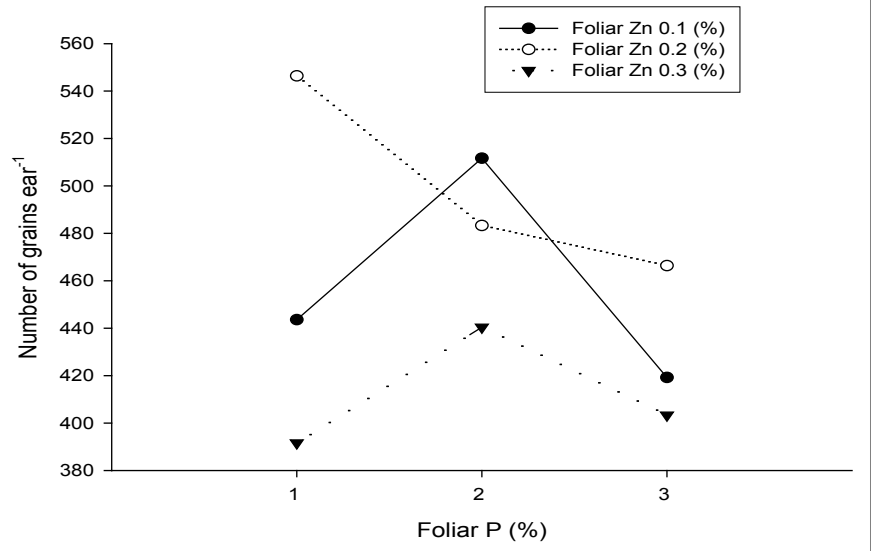

Figure 3: Interaction between foliar $\mathrm{P}$ and foliar $\mathrm{Zn}(\mathrm{P} \times \mathrm{Zn})$ influence number of grains ear $^{-1}$ in maize (Zea mays).

combinations (Figure 3). The combined application of $2 \%$ foliar $\mathrm{P}+0.1 \%$ foliar $\mathrm{Zn}$ stood second in the ranking in terms of higher number of grains ear ${ }^{-1}$ (Figure 3).

Thousand grains weight $(\mathrm{g})$ was significantly $(\mathrm{P}<0.05)$ affected by control vs. rest, foliar $\mathrm{P}$ and $\mathrm{Zn}$ levels, and $\mathrm{P} \times \mathrm{Zn}$ interaction (Table 1). The rest had significantly higher thousand grains weight $(216.6 \mathrm{~g})$ as compared to control (213.5 g) (Table 2).Among the foliar $\mathrm{Zn}$ levels, application of $0.2 \% \mathrm{Zn}$ gave highest thousand grains weight $(217.7 \mathrm{~g})$, while $0.1 \% \mathrm{Zn}$ gave lowest thousand grains weight (206.9 g). Among the foliar P levels, the highest thousand grains weight was obtained with $2 \%$ $\mathrm{P}$ (216.6 g), while the lowest thousand grains weight was recorded with $3 \% \mathrm{P}(205.5 \mathrm{~g})$. Interaction between $\mathrm{P} \times \mathrm{Zn}$ indicated that combination of $2 \%$ foliar $\mathrm{P}+0.2 \%$ foliar $\mathrm{Zn}$ increased 1000 grains weight in maize than any other foliar $\mathrm{P}$ and $\mathrm{Zn}$ combinations (Figure 4). The combined application of $1 \%$ foliar $\mathrm{P}+0.2 \%$ foliar $\mathrm{Zn}$ stood second in the ranking in terms of heavier grains (Figure 4).

\section{Yield and shelling percentage}

Biomass yield $\left(\mathrm{kg} \mathrm{ha}^{-1}\right)$ was significantly $(\mathrm{P}<0.05)$ affected by control vs. rest, foliar $\mathrm{P}$ and $\mathrm{Zn}$ levels, and interaction between foliar $\mathrm{P}$ and application time $(\mathrm{P} \times \mathrm{T})$ (Table 1$)$. The rest plots had significantly higher biomass yield $\left(9527 \mathrm{~kg} \mathrm{ha}^{-1}\right)$ as compared to control $(8841 \mathrm{~kg}$ $\mathrm{ha}^{-1}$ ) (Table 2). Among the foliar P levels, the highest biomass yield was obtained with 3\% P (9566 $\left.\mathrm{kg} \mathrm{ha}^{-1}\right)$ and the lowest biomass yield was obtained with $1 \% \mathrm{P}\left(9470 \mathrm{~kg} \mathrm{ha}^{-1}\right)$. Among the foliar Zn levels, the highest biomass yield was obtained with $0.3 \% \mathrm{Zn}\left(9754 \mathrm{~kg} \mathrm{ha}^{-1}\right)$ and the lowest biomass yield ( $9321 \mathrm{~kg} \mathrm{ha}^{-1}$ ) with $0.1 \%$ foliar $\mathrm{Zn}$. The interaction between $\mathrm{P} \times \mathrm{T}$ indicated that the biomass yield in maize increased significantly when any of the three P levels (1,2 and 3\% P) was applied at the early growth stage (booting) than applied late at silking stage of maize (Figure 5).

Grain yield $\left(\mathrm{kg} \mathrm{ha}^{-1}\right)$ of maize was significantly $(\mathrm{P}<0.05)$ affected by control vs. rest, foliar $\mathrm{P}$ and $\mathrm{Zn}$ levels, and interactions between $\mathrm{P}$ 


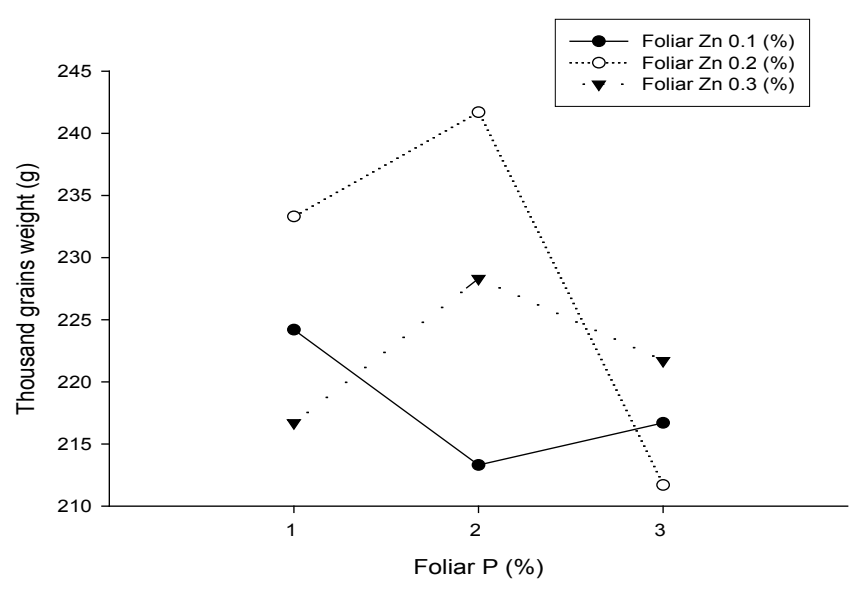

Figure 4: Interaction between foliar $P$ and foliar $Z n(P \times Z n)$ influence 1000 grains weight (g) in maize (Zea mays).

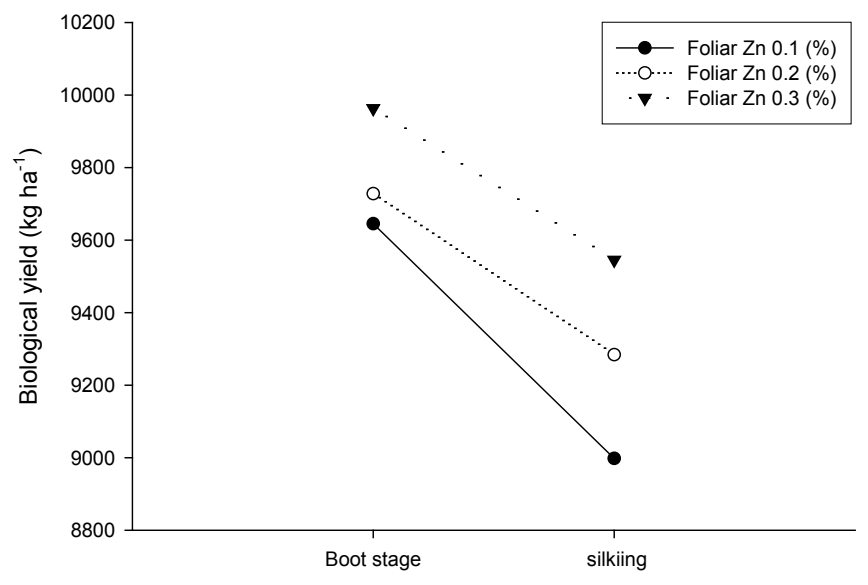

Figure 5: Interaction between foliar $P$ and application time $(P \times T)$ influence biological yield $\left(\mathrm{kg} \mathrm{ha}^{-1}\right)$ in maize (Zea mays).

$\times \mathrm{Zn}$ and $\mathrm{P} \times \mathrm{T}$ (Table 1$)$. The rest had significantly higher grain yield (3631 kg ha-1) as compared to control (3289 $\left.\mathrm{kg} \mathrm{ha}^{-1}\right)$ (Table 2). Among the foliar Zn levels, the highest grain yield $\left(3842 \mathrm{~kg} \mathrm{ha}^{-1}\right)$ was obtained with $0.3 \% \mathrm{Zn}$, while the lowest grain yield ( $\left.3446 \mathrm{~kg} \mathrm{ha}^{-1}\right)$ was obtained with $0.1 \%$ foliar $\mathrm{Zn}$. Among the foliar P levels, the highest grain yield (3707 $\mathrm{kg} \mathrm{ha}^{-1}$ ) was obtained with 3\% $\mathrm{P}$, while the lowest grain yield $\left(3560 \mathrm{~kg} \mathrm{ha}^{-1}\right.$ ) was obtained with $1 \% \mathrm{P}$. The interaction between $\mathrm{P} \times$ $\mathrm{Zn}$ indicated that the grain yield in maize increased significantly with the increase in both foliar P and Zn levels and vice versa (Figure 6). The interaction between $\mathrm{P} \times \mathrm{T}$ indicated that the grain yield in maize increased significantly when any of the three $\mathrm{P}$ level $(1,2$ and $3 \% \mathrm{P})$ was applied at the early growth stage (booting) than applied late at silking stage of maize (Figure 7).

Shelling percentage $(\%)$ was significantly $(\mathrm{P}<0.05)$ affected by control vs. rest, foliar $\mathrm{P}$ and $\mathrm{Zn}$ levels, and $\mathrm{Zn} \times \mathrm{T}$ interaction (Table 1). The rest had significantly higher shelling $(77.0 \%)$ as compared to control (72.0\%) (Table 2). Among the foliar P levels, maximum shelling percentage was obtained with $3 \% \mathrm{P}(78.2 \%)$, while the lowest shelling percentage was obtained with $1 \% \mathrm{P}(72.2 \%)$. Among the foliar $\mathrm{Zn}$ levels, maximum shelling percentage was obtained with $0.3 \% \mathrm{Zn}(80.8 \%)$ and the lowest shelling percentage was obtained with $0.1 \% \mathrm{Zn}$ (73.9\%). The interaction between $\mathrm{P} \times \mathrm{T}$ indicated that the shelling percentage in maize increased significantly when any of the three P levels $(1,2$ and $3 \% \mathrm{P}$ ) was applied at the early growth stage (booting) than applied late at silking stage of maize (Figure 8) and showed positive relationship with increase in grain yield.

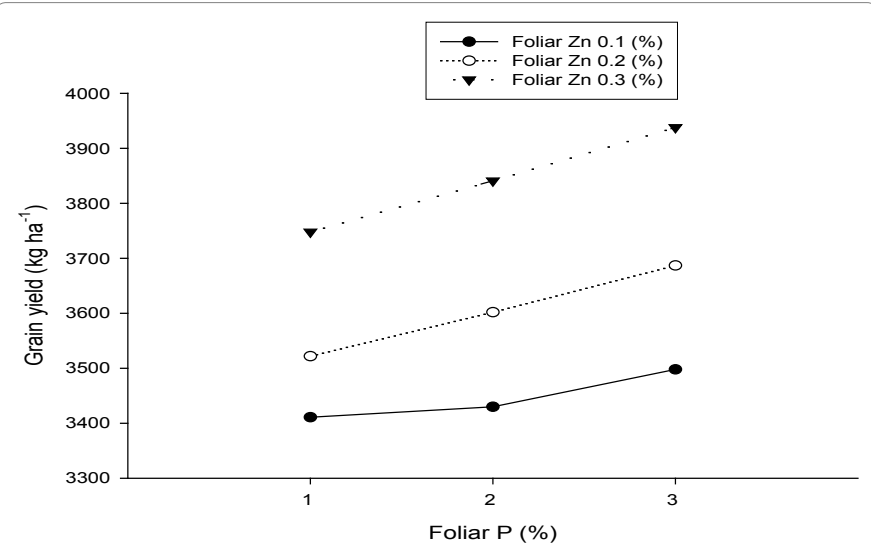

Figure 6: Interaction between foliar $\mathrm{P}$ and foliar $\mathrm{Zn}(\mathrm{P} \times \mathrm{Zn})$ influence grain yield $\left(\mathrm{kg} \mathrm{ha}^{-1}\right)$ in maize (Zea mays).

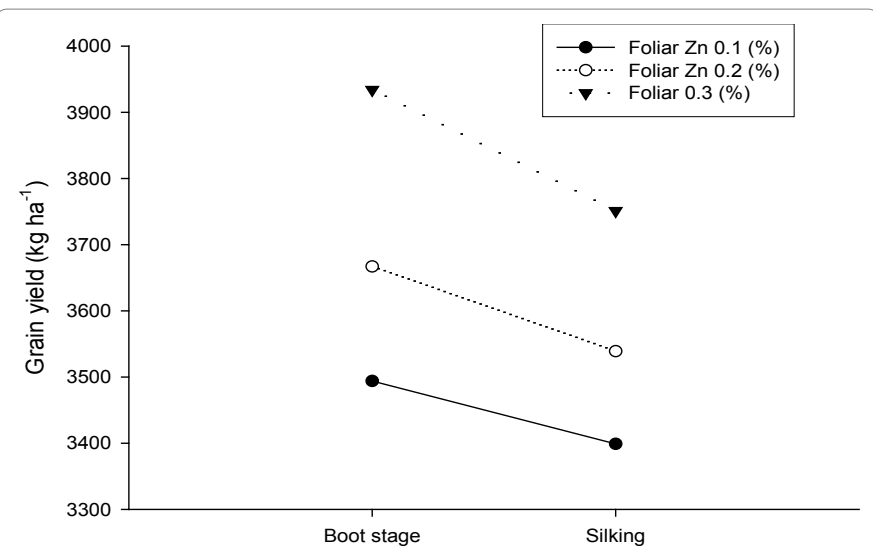

Figure 7: Interaction between foliar $\mathrm{P}$ and application time $(\mathrm{P} \times \mathrm{T})$ influence grain yield $\left(\mathrm{kg} \mathrm{ha}^{-1}\right)$ in maize (Zea mays).

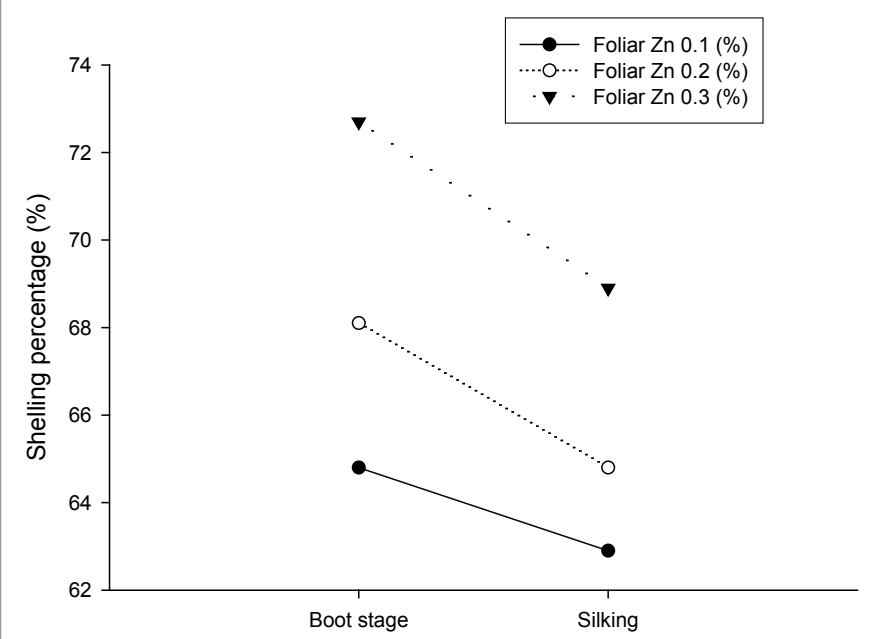

Figure 8: Interaction between foliar $\mathrm{P}$ and application time $(\mathrm{P} \times \mathrm{T})$ influence shelling (\%) in maize (Zea mays). 
Citation: Amanullah, Saleem A, lqbal A, Fahad S (2016) Foliar Phosphorus and Zinc Application Improve Growth and Productivity of Maize (Zea mays L.) Under Moisture Stress conditions in Semi-Arid Climates. J Microb Biochem Technol 8: 433-439. doi: 10.4172/1948-5948.1000321

\section{Discussion}

Both foliar $\mathrm{P}$ and $\mathrm{Zn}$ application improved the growth parameters (plant height and LAI) over control (no foliar $\mathrm{P}$ and $\mathrm{Zn}$ application) under calcareous soils in semiarid condition. Amanullah et al. [2] reported significant variation $(\mathrm{P}<0.05)$ in plant height and LAI of maize while spraying NPK at different growth stages. The increase in plant height with $\mathrm{P}$ and $\mathrm{Zn}$ application was earlier reported by many researchers [39-46]. Similarly, the increase in LAI in wheat with P and $\mathrm{Zn}$ application was earlier reported by Shukla and Warsi [47]. Other researchers [48]; Mohsin et al. [46] reported increase in the LAI of maize with foliar $\mathrm{Zn}$ application. The increase in LAI with $\mathrm{Zn}$ application probably may be due to increase in tryptophan amino acid and indole acetic acid hormone which are two main factors in leaf area expansion [49]. According to Firouzi [50], foliar spray of $\mathrm{Zn}$ increase LAI due to an increase in length and width of leaves with increase in auxin. Amanullah et al. [6] reported that foliar $\mathrm{N}$ application time had significant $(\mathrm{P}<0.05)$ effects, while foliar $\mathrm{N}$ source had no significant $(\mathrm{P}>0.05)$ effects on mean single leaf area of maize. Amanullah et al. [6] reported that foliar spray of $\mathrm{N}+\mathrm{P}+\mathrm{K}(2 \%$ each) resulted in maximum mean single leaf area, followed by foliar $\mathrm{N}$ application alone and the lowest mean single leaf area was observed with sole foliar $\mathrm{P}$.

The yield components (number of grains ear ${ }^{-1}$ and 1000 grains weight) also showed positive and significant $(\mathrm{P}<0.05)$ response to foliar P and $\mathrm{Zn}$ application over control. Earlier, Amanullah et al. [6] found that number of grains ear ${ }^{-1}$ in maize increased with foliar spray of NPK in combination over control. The increase in grains ear ${ }^{-1}$ with foliar P application are in agreement with those of Alston [51], they reported that grains spike ${ }^{-1}$ of wheat significantly increased with foliar $\mathrm{P}$. Similarly, Soleimani [52] reported marked increase in number of grains spike $^{-1}$ of wheat for foliar application $\mathrm{Zn}$. The tendency of increasing number of grains ear ${ }^{-1}$ with $\mathrm{Zn}$ application was also in line with the findings of many workers [53,54]. The increase in 1000 grains weight in maize with foliar nutrition was in accordance with our early study [6]. According to Samad et al. [55], the combine application of soil and foliar applied P increased 1000-grains weight over control but did not improve it over the sole application of soil or foliar applied P. Tahir et al. [43] and Mohsin et al. [46], reported increase in the 1000-grains weight with foliar $\mathrm{Z}$ application over control. These results are in line with the results of Guenis et al. [56], Soylu et al. [57], Harris et al. [54] and Farajzadeh et al. [58]; they reported significant increase in thousand grains weight with foliar application of micronutrients.

Both biomass and grain yields as well as shelling increased significantly $(\mathrm{P}<0.05)$ with foliar $\mathrm{P}$ and $\mathrm{Zn}$ application over control and the increase was more when foliar nutrients were applied at boot stage than applied at silking. The increase in biomass yield with foliar nutrition was attributed to the improvement in growth parameters, yield and yield components of maize. According to Amanullah et al. [6], combined foliar application of the three major nutrients $(\mathrm{N}+\mathrm{P}+\mathrm{K})$ at the rate of $1 \%$ each in two equal splits at 30 and 60 days after emergence increased maize productivity under moisture stress condition under semiarid condition. Many researchers [20,59] reported increase in grain and biomass yields with foliar P. Other researchers $[46,60]$ showed positive response of biomass and grain yields to foliar $\mathrm{Zn}$ application. The increase in biomass yield with foliar application of $\mathrm{Zn}$ probably might be due to their critical role of $\mathrm{Zn}$ in crop growth, involving in photosynthesis processes, respiration and other biochemical and physiological activates and thus their importance in achieving higher yields [61]. Higher yield due to $\mathrm{Zn}$ fertilization was also attributed to the enhanced synthesis of carbohydrates and their transport to the site of grain production [62-65].

\section{Conclusion}

The foliar $\mathrm{P}$ and $\mathrm{Zn}$ treated plots (rest) had better performance in terms of improved growth, higher yield and yield components than control (no foliar spray). Application of foliar $\mathrm{P}$ at the rate of $3 \%$ and $\mathrm{Zn}$ at the rate of $0.3 \%$ improved growth, increased yield and yield components of maize under moisture stress condition. Early application of foliar $\mathrm{P}$ and $\mathrm{Zn}$ at boot stage had positive impact on growth, yield and yield components of maize as compared to late spray at silking.

\section{References}

1. MINFAL (2012) Agricultural statistics of Pakistan. Government of Pakistan. Ministry of Food Agri. Livestock, Food Agricultural and Livestock, Division (Economic wing) Islamabad.

2. Amanullah, Inamullah (2014) Preceding rice genotypes, residual phosphorus and zinc influence crop productivity under rice-wheat cropping system. $4^{\text {th }}$ International \& $13^{\text {th }}$ National Conference of Botany at SBB University, Sheringal, Upper Dir, Khyber Pakhtunkhwa.

3. Amanullah (2014a) Effects of variable nitrogen source and rate on leaf area index and total dry matter accumulation in maize (Zea mays L.) genotypes under calcareous soils. Turkish J Field Crops 19: 276-284.

4. Amanullah M, Asif SS, Malhi RA, Khattak (2009) Effects of P-fertilizer source and plant density on growth and yield of maize in Northwestern Pakistan. J Plant Nutr 32: 2080-2093.

5. Amanullah $M$, Shah $P(2010)$ Timing and rate of nitrogen application influence grain quality and yield in maize planted at high and low densities. J Sci Food \& Agric 15: 21-29.

6. Amanullah A, Khan Z, Khan F (2013) Foliar application of nitrogen at different growth stages influence the phenology, growth and yield of maize (Zea mays L). Soil \& Environment 32: 135-140.

7. Amanullah (2014b) Source and rate of nitrogen application influence agronomic $\mathrm{N}$-use efficiency and harvest index in maize (Zea mays $\mathrm{L}$ ) genotypes. Maydica 59: 80-89

8. Amanullah LK, Almas, Shah P (2010a) Timing and rate of nitrogen application influence profitability of maize planted at low and high densities in Northwest Pakistan. Agron J 102: 575-579.

9. Amanullah M, Zakirullah, Khalil SK (2010b) Timing and rate of phosphorus application influence maize phenology, yield and profitability in Northwest Pakistan. Intl J Plant Production 4: 281-292.

10. Amanullah M, Khan W (2011) Interactive effect of potassium and phosphorus on grain quality and profitability of sunflower in Northwest Pakistan. Pedosphere. 21: 532-538.

11. Amanullah M, Asif LK, Almas (2012) Agronomic efficiency and profitability of P-fertilizers applied at different planting densities of maize in Northwest Pakistan. J Plant Nutr 35: 331-341.

12. Clarkson DT (1981) Nutrient interception and transport by root systems. Butterworths 307-330.

13. Eichert TJ, Burkhardt J (1999) A novel model system for the assessment of foliar fertilizer efficiency. In Technology and Applications of foliar fertilizers. Proceedings of the Second International Workshop on Foliar Fertilization, Bangkok.

14. Tyree M, Scherbatskoy D, Tabor CA (1990) Leaf cuticles behave as asymmetric membranes: Evidence from measurement of diffusion potentials. Plant Physiology 92: 103-109.

15. Sherchand K, Paulsen GM (1985) Response of wheat to foliar phosphorus treatments under field and high temperature regimes. J Plant Nutri. 12: 11711181.

16. Batten GD, Wardlaw IF, Aston MJ (1986) Growth and the distribution of phosphorus in wheat developed under various phosphorus and temperature regimes. Aus J Agric Res 3: 459-469.

17. Qaseem SM, Afridi MM, Samiullah RK (1978) Effect of leaf applied phosphorus on the yield characteristics of ten barley varieties. Indian J Agric Sci 48: 215-217.

18. Ling F, Silberbush M (2002) Response of maize to foliar versus soil application of nitrogen-phosphorus-potassium fertilizers. J Plant Nutri 11: 2333-2342. 
Citation: Amanullah, Saleem A, lqbal A, Fahad S (2016) Foliar Phosphorus and Zinc Application Improve Growth and Productivity of Maize (Zea mays L.) Under Moisture Stress conditions in Semi-Arid Climates. J Microb Biochem Technol 8: 433-439. doi: 10.4172/1948-5948.1000321

19. Haloi B (1980) Effect of foliar application of phosphorus salt on yellowing of wheat seedlings. J Res Assam Agric Uni 1: 108-109.

20. Dixon RC (2003) Foliar fertilization improves nutrient use efficiency. Fluid Journal 11: 22-23.

21. Outten CE, O'Halloran TV (2001) Femtomolar sensitivity of metalloregulatory protein controlling $\mathrm{Zn}$ homeostasis. Science 292: 2488-2492.

22. Pandey N, Pathak GC, Sharma CP (2006) Zinc is critically required for pollen function and fertilization in lentil. J Trace Elements in Medicine and Biol 20: 89-96.

23. Alloway B (2004) Zinc in soils and crop nutrition. Areas of the World with Zinc Deficiency Problems

24. Cakmak I (2008) Enrichment of cereal grains with zinc: Agronomic or genetic biofortification? Plant and Soil 302: 1-17.

25. Bagei SA, Ekiz H, Yilmaz A, Cakmak I (2007) Effects of zinc deficiency and drought on grain yield of field-grown wheat cultivars in Central Anatolia. J Agron Crop 193: 198-206.

26. Sharafi S, Tajbakhsh M, Majidi M, Pourmirza A (2002) Effect of iron and zinc fertilizer on yield and yield components of two forage corn cultivars in Urmia. Soil and Water 12: 85-94

27. Mahaleh JK, Roshdi M (2008) Effect of low-used elements spraying on qualitative and quantitative properties of silo corn 704 in Khoy. Seed and Plan 24: 281-293.

28. Salimpour S, Khavazi K, Nadian H, Besharati H, Miransari M (2010) Enhancing phosphorous availability to canola (Brassica napus L.) using $\mathrm{P}$ solubilizing and sulfur oxidizing bacteria. Aust J Crop Sci 4: 330-334.

29. Khorgamy A, Farnis A (2009) Effect of phosphorus and zinc fertilisation on yield and yield components of chick pea cultivars. African Crop Science Conference Proceedings 9: 205-208.

30. Erenoglu B, Nikolic M, Römhold V, Cakmak I (2002) Uptake and transport of foliar applied zinc in bread and durum wheat cultivars differing in zinc efficiency. Plant and Soil 241: 251-257.

31. Grzebisz W, Wrońska M, Diatta JB, Dullin P (2008) Effect of zinc foliar application at early stages of maize growth on patterns of nutrients and dry matter accumulation by the canopy. Part I. Zinc uptake patterns and its redistribution among maize organs. J Elementolgy 13: 17-28.

32. Leach KA, Hameleers A (2001) The effects of a foliar spray containing phosphorus and zinc on the development, composition and yield of forage maize. Grass Forage Sci 56: 311-315.

33. Yosefi K, Galavi M, Ramrodi M, Mousavi SR (2011) Effect of bio-phosphate and chemical phosphorus fertilizer accompanied with micronutrient foliar application on growth, yield and yield components of maize (Single Cross 704). Aust J Crop Sci 5: 175-180

34. Abd El-Baky, MMH, Ahmed AA, El-Nemr MA, Zaki MF (2010) Effect of potassium fertilizer and foliar zinc application on yield and quality of sweet potato. Res J Agric Biol Sci 6: 386-394.

35. Aghtape AA, Ghanbari A, Sirousmehr A, Siahsar B, Asgharipour M, et al. (2011) Effect of irrigation with wastewater and foliar fertilize application on some forage characteristics of foxtail millet. Int J Plant Physiol Biochem 3: 34-42.

36. Amanullah, Khalid S (2016) Integrated use of phosphorus, animal manures and biofertilizers improve maize productivity under semiarid condition. Organic Fertilizers - From Basic Concepts to Applied Outcomes. InTech, Rijeka, Croatia.

37. Amanullah, Khan A (2015) Phosphorus and compost management influence maize (Zea mays) productivity under semiarid condition with and without phosphate solubilizing bacteria. Frontiers in Plant Science (Plant Biotic Interactions) 6: 1083

38. Steel RGD, Torrie JH, Dickey D (1996) Principals and procedures of statistics. McGraw Hill, USA

39. Kausar K, Akbar M, Rasul E, Ahmad AN (1993) Physiological response of nitrogen, phosphorus and potassium on growth and yield of wheat. Pakistan. $J$ Agric Res 14: 126-130.

40. Singaram P, Kothandaraman GV (1994) Studies on residual, direct and cumulative effect of phosphorus sources on the availability, content and uptake of phosphorus and yield of maize. Madras Agric J 81: 425- 429.
41. Allmarus RR, Pumphrey EV, Cochlar FE, Robert S (1998) Method and rate of supplying $\mathrm{ZnSO}_{4}$ for corn on $\mathrm{Zn}$ deficient soil in west Nebraska. Agron J 53: 236-238.

42. Sahoo SC, Panda M (2001) Effect of phosphorus and detasseling on yield of babycorn. Indian J Agri Sci 71: 21-22.

43. Tahir M, Fiaz N, Nadeem MA, Khalid F, Ali M (2009) Effect of different chelated zinc sources on the growth and yield of maize (Zea mays L.). Soil Environ. 28 179-183.

44. El-Badawy, EI M, Mehasen SAS (2011) Multivariate analysis for yield and its components in maize under zinc and nitrogen fertilization levels. Aust $\mathrm{J}$ Basic \& Appl Sci 5: 3008-3015

45. Piri I (2012) Effect of phosphorus fertilizer and micronutrients foliar application on sorghum yield. Annals. Biol Res 3: 3998-4001.

46. Mohsin AU, Ahmad M, Farooq, Ullah S (2014) Influence of zinc application through seed treatment and foliar spray on growth, productivity and grain quality of hybrid maize. J Animal \& Plant Sci 24: 1494-1503.

47. Shukla SK, Warsi AS (2000) Effect ofsulpher and micronutrients on growth, nutrient content and yield of wheat (Triticum aestivum) Indian J. Agri. Res. 34: 203-205.

48. Safyan N, Naderidarbaghshahi MR, Bahari B (2012) The effect of microelements spraying on growth, qualitative and quantitative grain corn in Iran. Intl R J App Basic Sci 3: 2780-2784.

49. Seifi-Nadergholi M, Yarnia M, Rahimzade KF (2011) Effect of zinc and manganese and their application method on yield and yield components of common bean (Phaseolus vulgaris L. CV. Khomein). Middle-East J. Sci. Res. 8: 859-865.

50. Firouzi M (2005) The effect of foliar absorption of microelements on growth and yield of foliage corn. MS thesis in Agronomy, Agriculture College, Islamic Azad University, Khorasgan Branch.

51. Alston AM (1979) Effects of soil water content and foliar fertilization with nitrogen and phosphorus in late season on the yield and composition of wheat. Aus J Exper Agric Anim Husb 30: 577-585.

52. Soleimani R (2006) The effects of integrated application of micronutrient on wheat in low organic carbon conditions of alkaline soils of western Iran. Soil Sci 21: 382-385

53. Bakyt K, Sade B (2002) Response of field grown barley cultivars grown on zinc deficient soil to zinc application. Comm Soil Sci Plant Anal 33: 533-544.

54. Harris D, Rashid A, Miraj G, Arif M, Shah H (2007) On farm' seed priming with zinc sulphate solution - a cost effective way to increase the maize yields of resource - poor farmers. Field Crops Res 102: 119-127.

55. Samad A, Muhammad D, Musarat M, Ullah W (2014) Enhancing wheat yield and phosphorus use efficiency through foliar application in calcareous soil. $J$ Natur Sci Res 4: 70-74.

56. Guenis A, Alpaslan M, Unal A (2003) Effects of boron fertilization on the yield and some yield components of bread and durum wheat. Turk J Agric 27 329-335.

57. Soylu SB, Sade A, Topal N, Akgun S, Gezgin (2005) Responses of irrigated durum and bread wheat cultivars to boron application in low boron calcareous soil Turk. J Agric 29: 275-286.

58. Farajzadeh MT, Khorshidi MB, Ahmadzadeh V (2009) Effect of micronutrients and their application method on yield, crop growth rate and net assimilation rate of corn. J Food Agric Envir 7: 611-615.

59. Poulsen KH, Nagy R, Gao LL, Smith SE, Bucher M, et al. (2005) Physiologica and molecular evidence for $P$ uptake via the symbiotic pathway in reduced mychorhizal colonization with a compatible fungus. New Phytologist. 168: 445 453

60. Thalooth M, Tawfik M, Mohamed MH (2006) A comparative study on the effect of foliar application of zinc, potassium and magnesium on growth, yield and some chemical constituents of mung bean plants growth under water stress conditions. World J Agric 2: 37-46.

61. Zeidan MS, Manal F, Hamouda HA (2010) Effect of foliar fertilization of Fe, Mn and $\mathrm{Zn}$ on wheat yield and quality in low sandy soils fertility. World J Agric Sc 6: 696-699. 
Citation: Amanullah, Saleem A, Iqbal A, Fahad S (2016) Foliar Phosphorus and Zinc Application Improve Growth and Productivity of Maize (Zea mays L.) Under Moisture Stress conditions in Semi-Arid Climates. J Microb Biochem Technol 8: 433-439. doi: 10.4172/1948-5948.1000321

62. Pedda-Babu P, Shanti M, Prasad BR, Minhas PS (2007) Effect of zinc on rice in rice - black gram cropping system in saline soils. Andhra Agric $\mathrm{J}$ 54: 47-50.

63. Amanullah K, Kakar M, Khan A, Khan I, Shah Z (2014) Growth and yield response of maize (Zea mays L.) to foliar NPK-fertilizers under moisture stress condition. Soil \& Environ 33: 116-123.
64. Amanullah M, Yasir SK, Khalil MT (2010) Phenology, growth and grain yield of maize as influenced by foliar applied urea at different growth stages. J Plant Nutri 33: 71-79.

65. Girma K, Raun B, Zhang H, Mosali J (2006) What about foliar P on corn and winter wheat. Fluid J 14: 17-19. 